\section{Keterampilan Berpikir Kreatif Peserta Didik yang Diajar Melalui Model Pembelajaran Pjbl dan Model Konvensional Materi Pencemaran Lingkungan}

\section{Sitti Ashriah}

Abd. Muis

\section{A. Faridah Arsal}

\begin{abstract}
Abstrak. Penelitian ini bertujuan untuk mengetahui perbedaan keterampilan berpikir kreatif peserta didik yang diajar menggunakan model pembelajaran PjBL dan pembelajaran konvensional materi pencemaran lingkungan. Penelitian ini merupakan penelitian quasi experiment dengan bentuk pretest-postest control group design. Sampel penelitian ini adalah siswa kelas VII A dan VII C yang berjumlah 34 orang. Teknik pengumpulan data dalam penelitian ini menggunakan tes uraian. Analisis data dalam penelitian ini dilakukan dengan Uji-t. Hasil penelitian menunjukan bahwa (1) keterampilan berpikir kreatif peserta didik yang diajar menggunakan model pembelajaran PjBL materi pencemaran lingkungan berada pada kategori cukup dengan nilai rata-rata sebesar 58,23; (2) keterampilan berpikir kreatif peserta didik yang diajar menggunakan model pembelajaran konvensional materi pencemaran lingkungan berada pada kategori kurang dengan nilai rata-rata sebesar 46,70; (3) ada perbedaan keterampilan berpikir kreatif peserta didik yang diajar menggunakan model pembelajaran PjBL dan model pembelajaran konvensional dimana peserta didik yang diajar melalui model pembelajaran PjBL memiliki keterampilan berpikir kreatif lebih tinggi dibanding yang diajar melalui model pembelajaran konvensional.

Kata kunci: keterampilan berpikir kreatif, project-based learning, pembelajaran konvensional.
\end{abstract}

\section{Pendahuluan}

Mata pelajaran Biologi tersusun secara sistematis, dimulai dari materi dasar yang sederhana hingga yang kompleks. Apabila peserta didik mampu menguasai konsep dasar akan mudah mengikuti pelajaran berikutnya. Kenyataan di lapangan bahwa pelajaran Biologi masih dianggap mata pelajaran yang sulit. Pandangan ini menyebabkan peserta didik tidak atau kurang termotivasi terhadap pelajaran Biologi. Oleh karena itu menjadi tanggung jawab seorang guru untuk melakukan perbaikan dalam proses belajar mengajar. Berdasarkan alasan tersebut, maka sangatlah penting bagi para pendidik khususnya guru memahami karakteristik materi, peserta didik dan metodologi pembelajaran dalam proses pembelajaran. Agar proses pembelajaran lebih variatif, inovatif dan efesien dalam membangun wawasan pengetahuan dan implementasinya sehingga dapat meningkatkan aktivitas dan kreativitas peserta didik (Akbar dan Bahri, 2017). Kreativitas pada intinya merupakan kemampuan seseorang untuk melahirkan sesuatu yang baru, baik berupa gagasan maupun karya nyata, baik dalam bentuk ciri-ciri aptitude

\section{Biology Teaching \\ and Learning}

p-ISSN $2621-5527$
e-ISSN $2621-5535$

Abstract. This research aims to find out the difference of students' creative thinking skill using the PjBL learning model and conventional learning model for environmental pollution material. This research is a quasi-experiment with pretest-posttest control group design. The population were all the students of class VII and the sample were 34 students of class VII A and VII

C. Data collection techniques used an essay. Data analysis in this study was conducted by $t$-test. The results showed that (1) creative thinking skill of

students taught using PjBL learning model of environmental pollution material are in the moderate category with an average value of 58.23; (2) creative thinking skill of students

taught using conventional learning model of environmental pollution are in the low category with an average value of 46.70; (3) there is difference of students' creative thinking skill using PjBL learning model and conventional learning model of environmental pollution materials where students taught through PjBL learning model

have higher creative thinking skills than taught by conventional learning model.

Keywords: creative thinking skill, project-based learning, coventional learning.

Sitti Ashriah

Universitas Negeri Makassar Indonesia

Abd. Muis

Universitas Negeri Makassar Indonesia

A. Faridah Arsal Universitas Negeri Makassar Indonesia 
maupun non aptitude, baik dalam karya baru maupun kombinasi dengan hal-hal yang sudah ada, yang semuanya itu relatif berbeda dengan apa yang telah ada sebelumnya (Reni dalam Suriyani dkk, 2015).

Menurut model Williams dalam Sugiono (2009) menyatakan bahwa perilaku siswa yang termasuk dalam keterampilan kognitif kreatif yang mencerminkan indikator sebagai berikut: 1) Berpikir lancar (Fluent thinking)/kelancaran (menghasilkan banyak gagasan); 2) Berpikir luwes (Flexible thinking)/kelenturan (menghasilkan gagasan-gagasan yang seragam); 3) Berpikir orisinil (Original thinking) (memberikan jawaban yang lain daripada yang lain) dan 4) Berpikir terperinci (Elaboration) yang menyebabkan seseorang mampu mengembangkan/memperkaya suatu gagasan.

Keterampilan berpikir kreatif merupakan salah satu tujuan yang harus dicapai dalam pembelajaran biologi di sekolah. Kreativitas atau berpikir kreatif tidak bisa muncul dengan sendirinya melainkan butuh suatu latihan. Dalam hal ini guru harus bisa melatih dan mengasah kemampuan berpikir kreatif peserta didik dengan pembelajaran yang memunculkan permasalahan-permasalahan sehari-hari (Meika \& Sujana, 2017).

Kurikulum 2013 adalah sebuah kurikulum yang dirancang untuk menyiapkan peserta didik dalam menghadapi tantangan dimasa depan, yaitu tuntutan globalisasi dan kemajuan teknologi informasi. Penerapan K13 didukung oleh model-model pembelajaran yang mengaktifkan peserta didik baik kognitifnya, psikomotoriknya dan afektifnya. Salah satu model pembelajaran yang direkomendasikan oleh kurikulum 2013 adalah model pembelajaran project-based learning. Model PjBL merupakan suatu model pembelajaran yang menitik beratkan proses belajar mengajar siswa dengan melaksanakan proyek dan menghasilkan produk sebagai output dari pembelajaran yang telah dilakukan (Luthfi dkk, 2018).

Setiap manusia pada dasarnya membutuhkan proses berpikir di setiap aspek kehidupannya. Berpikir menjadi salah satu penyebab seseorang dapat menghasilkan suatu produk dan juga menyelesaikan permasalahan (Syamsu dkk, 2016).

Pembelajaran Project Based Learning diterapkan untuk menumbuhkan peserta didik lebih aktif dan berinisiatif untuk memperoleh pengetahuan, pemahaman dan keterampilannya, karena Project Based Learning mengkondisikan dan memaksa mereka mau mencari solusi pemecahan untuk menuntaskan proyeknya sehingga menuntut peserta didik untuk berpikir kreatif. Pembelajaran berbasis proyek memiliki potensi yang sangat besar untuk melatih proses berpikir peserta didik yang mengarah pada kemampuan berpikir kreatif peserta didik.

Berdasarkan hasil wawancara dengan guru bidang studi biologi di SMP Negeri 1 Malili diketahui bahwa dalam kegiatan belajar mengajar peserta didik cenderung pasif. Guru masih menggunakan model pembelajaran konvensional dalam proses pembelajaran yaitu berpusat pada guru (teacher centered). Dalam model pembelajaran konvensional, guru dituntut lebih berperan aktif sebagai penyampai informasi. Akibatnya peserta didik kurang aktif dan berinisiatif untuk memperoleh pengetahuan. Banyak peserta didik yang belum paham materi yang diajarkan, hal ini dikarenakan banyaknya peserta didik yang terjebak dalam kondisi pembelajaran yang menggunakan metode ceramah. Dengan demikian, peneliti mengajukan judul "Perbedaan Keterampilan Berpikir Kreatif Yang Diajar Melalui Model Pembelajaran Pjbl Dan Model Konvensional Materi Pencemaran Lingkungan".

\section{Metode Penelitian}

\section{Jenis dan Desain Penelitian}

Jenis penelitian yang digunakan dalam penelitian ini adalah eksperimen semu (Quasy experiment). Desain penelitian yang digunakan dalam penelitian ini adalah pretest-postest control grup design. 
(hlm. 52-59)

Desain penelitian ini terdiri atas dua kelompok yang ditentukan secara random (acak).

Pada kelompok pertama sebagai kelompok eksperimen diberi perlakuan dengan model pembelajaran PjBL dan kelompok lain sebagai kelompok kontrol diberi pembelajaran dengan metode ceramah yang biasa dilakukan oleh guru. Kedua kelompok tersebut terlebih dahulu diberikan pretest dan pada akhir diberikan posttest, kemudian hasil dari kedua kelompok tersebut dibandingkan.

\section{Definisi Operasional}

1. Model pembelajaran PjBL adalah model pembelajaran dimana peserta didik melaksanakan suatu proyek berdasarkan permasalahan (problem) dalam jangka waktu tertentu secara kolaboratif yang kemudian hasilnya ditampilkan atau dipresentasikan.

2. Model pembelajaran konvensional adalah model pembelajaran yang ditandai dengan ceramah dari guru diiringi dengan penjelasan, serta pembagian tugas dan latihan.

3. Keterampilan berpikir kreatif adalah keterampilan seseorang dalam berfikir untuk menghasilkan sesuatu yang baru dimana sebelumnya belum ada atau sebelumnya sudah ada namun dikembangkan atau dikombinasikan berdasarkan dua atau lebih ide-ide yang telah ada.

\section{Populasi dan Sampel}

Populasi penelitian adalah siswa kelas VII SMP Negeri 1 Malili. Sedangkan sampelnya adalah kelas VII A sebagai kelas eksperimen dan kelas VII C sebagai kelas kontrol. Masingmasing kedua kelas tersebut berjumlah 17 siswa sehingga jumlah totalnya 34 siswa.

\section{Tempat dan Waktu Penelitian}

Penelitian ini dilaksanakan di SMP Negeri 1 Malili. Waktu penelitian dilakukan pada semestar genap tahun ajaran 2018/2019. Peneliti mengajarkan materi pencemaran lingkungan pada kelas eksperimen dan kelas kontrol masing-masing sebanyak 6 kali pertemuan, yaitu 1 kali pertemuan dilaksanakan untuk tes kemampuan awal (pretest), 4 kali pertemuan dilaksanakan untuk proses belajar mengajar, 1 kali pertemuan dilaksanakan untuk evaluasi atau tes akhir (posttest).

\section{Tehnik Pengumpulan Data}

Pengumpulan data dalam penelitian ini dilakukan dengan memberikan soal ujian dalam bentuk tes uraian yang telah diuji validitasnya untuk mengukur keterampilan berpikir kreatif peserta didik. Data mengenai keterampilan berpikir kreatif peserta didik diperoleh melalui pretest (tes awal) dan posttest (tes akhir).

Dari jumlah skor yang diperoleh tersebut selanjutnya dianalisis untuk menentukan nilai keterampilan berpikir kreatif peserta didik yang diperoleh dengan menggunakan rumus Arikunto (2009) sebagai berikut:

$$
\text { Nilai }=\frac{\text { Skor yang diproleh }}{\text { Skor maksimal }} \times 100
$$


p-ISSN 2621-5527

e-ISSN 2621-5535
Keterampilan Berpikir Kreatif Peserta Didik yang Diajar Melalui Model Pembelajaran Pjbl dan Model Konvensional Materi Pencemaran Lingkungan (hlm. 52-59)

\section{Tekhnik Analisis Data}

Data yang diperoleh mengenai keterampilan berpikir kreatif peserta didik, selanjutnya dianalisis dengan menggunakan dua cara yaitu analisis statistik deskriptif dan analisis statistik inferensial. Analisis statistik deskriptif terdiri dari nilai rata-rata (mean), standar deviasi, nilai tertinggi dan nilai terendah dengan menggunakan SPSS. Pada penelitian ini untuk menyajikan data keterampilan berpikir kreatif, skor yang telah diperoleh kemudian dikonversikan dalam kategori nilai persentase keterampilan berpikir kreatif peserta didik.

Tabel 1. Kategori Keterampilan Berpikir Kreatif

\begin{tabular}{|c|c|}
\hline Nilai & Kategori \\
\hline $80-100$ & Sangat Baik \\
\hline $66-79$ & Baik \\
\hline $56-65$ & Cukup \\
\hline $40-55$ & Kurang \\
\hline $0-39$ & Sangat Kurang \\
\hline
\end{tabular}

(Sumber: Arikunto, 2018)

Sedangkan analisis statistik inferensial dalam penelitian ini digunakan untuk menguji hipotesis menggunakan uji t melalui sistem Statictical Package of Sosial Science. Sebelum dilakukan uji hipotesis terlebih dahulu dilakukan uji normalitas dan uji homogenitas. Syarat yang harus dipenuhi untuk pengujian hipotesis adalah data yang diperoleh terdistribusi normal dan mempunyai variansi yang homogen.

\section{Hasil dan Pembahasan}

Hasil penelitian diperoleh dari 34 peserta didik, kelas VII A sebagai kelas eksperimen sebanyak 17 peserta didik dan kelas VII C sebagai kelas kontrol sebanyak 17 peserta didik. Pada kelas eksperimen, pembelajaran dilakukan dengan menggunakan model Project Based Learning (PjBL) sedangkan pada kelas kontrol menggunakan model konvensional. Hasil penelitian tersebut diuraikan sebagai berikut.

Tabel 2. Analisis Statistik Deskriptif Keterampilan Berpikir Kreatif Peserta didik Kelompok Eksperimen

\begin{tabular}{|c|c|c|}
\hline \multirow{2}{*}{$\begin{array}{c}\text { Statistik } \\
\text { Deskriptif }\end{array}$} & \multicolumn{2}{|c|}{$\begin{array}{c}\text { Keterampilan } \\
\text { Berpikir Kreatif }\end{array}$} \\
\cline { 2 - 3 } & Pretest & Posttest \\
\hline Sampel (N) & 17 & 17 \\
\hline Nilai minimum & 33 & 36 \\
\hline Nilai maksimum & 66 & 89 \\
\hline Rata-rata & 49,76 & 58,24 \\
\hline
\end{tabular}


(hlm. 52-59)

\section{Tabel 3. Analisis Statistik Deskriptif Keterampilan Berpikir Kreatif Peserta didik Kelompok Kontrol}

\begin{tabular}{|c|c|c|}
\hline \multirow{2}{*}{$\begin{array}{c}\text { Statistik } \\
\text { Deskriptif }\end{array}$} & \multicolumn{2}{|c|}{$\begin{array}{c}\text { Keterampilan } \\
\text { Berpikir Kreatif }\end{array}$} \\
\cline { 2 - 3 } & Pretest & Posttest \\
\hline Sampel (N) & 17 & 17 \\
\hline Nilai minimum & 26 & 26 \\
\hline Nilai maksimum & 86 & 68 \\
\hline Rata-rata & 45,82 & 46,71 \\
\hline
\end{tabular}

Dapat dilihat bahwa sampel $(\mathrm{N})$ dalam penelitian terlihat pada tabel tersebut adalah 17 peserta didik dengan nilai rerata (mean) untuk pretest kelompok eksperimen sebesar 49,76 dan untuk posttest sebesar 58,24. Sedangkan kelompok kontrol yang dibelajarkan dengan model konvensional terlihat bahwa nilai rerata (mean) untuk pretest sebesar 45,82 dan untuk posttest sebesar 46,71 .

Hal ini menunjukkan bahwa keterampilan berpikir kreatif kelas eksprimen lebih baik dibandingkan keterampilan berpikir kreatif di kelas kontrol.

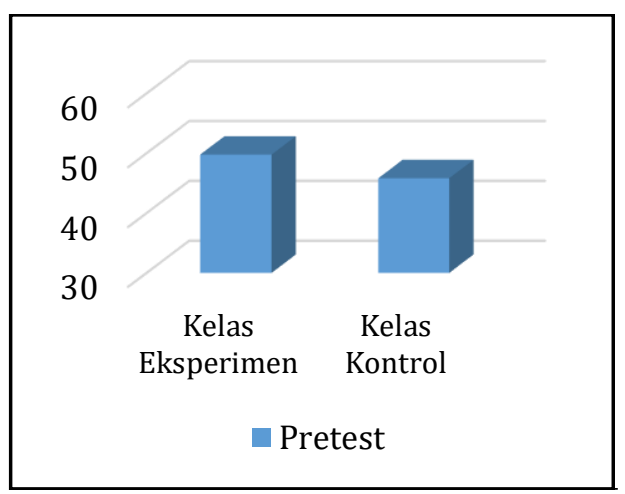

\section{Gambar 1. Diagram Rata-Rata Perolehan Skor Pretest Keterampilan Berpikir Kreatif}

Berdasarkan skor pretest, diketahui bahwa peserta didik kelas eksperimen mempunyai keterampilan berpikir kreatif yang masih rendah. Hal tersebut dapat dilihat dari perolehan skor rata-rata hasil pretes kelas eksperimen sebesar 49,76.

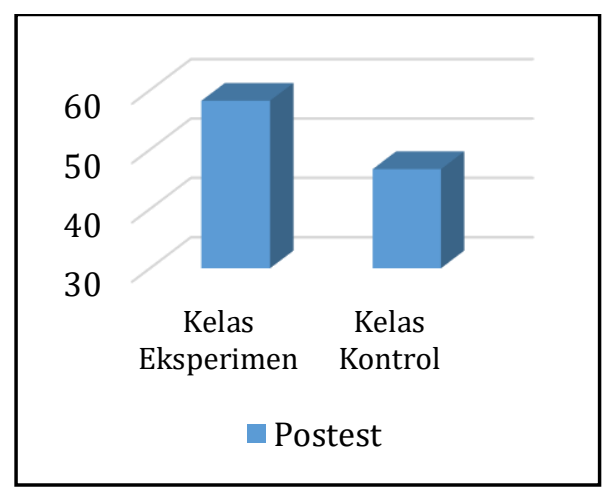

Gambar 2. Diagram Rata-Rata Perolehan Skor Postest Keterampilan Berpikir Kreatif 
Setelah dilakukan proses pembelajaran dengan menggunakan model PjBL, terdapat peningkatan. Skor rata-rata hasil postest kelas eksperimen menjadi sebesar 58,24. Hal tersebut menunjukkan penerapan model PjBL mempunyai dampak yang konsisten terhadap keterampilan berpikir kreatif peserta didik.

\section{Tabel 3. Nilai Hasil Pretest dan Posttest Kelompok Kontrol dan Kelompok Eksperimen}

\begin{tabular}{|c|c|c|c|c|}
\hline \multicolumn{2}{|c|}{ Data tes keterampilan berpikir kreatif } \\
\hline $\begin{array}{c}\text { Parameter } \\
\text { Perbandingan }\end{array}$ & \multicolumn{2}{|c|}{ Eksperimen } & \multicolumn{2}{c|}{ Kontrol } \\
\cline { 2 - 5 } & Pretest & Postest & Pretest & Postest \\
\hline Skor & 49,76 & 58,23 & 45,82 & 46,70 \\
\hline Kriteria & Kurang & Cukup & Kurang & Kurang \\
\hline
\end{tabular}

Terdapat keterampilan berpikir kreatif yang diajar melalui model pembeajaran PjBL pada materi pencemaran lingkungan. Hal ini dapat dilihat dari kelas yang menerapkan model PjBL dengan nilai rata-rata lebih tinggi dibandingkan kelas yang menggunakan model pembelajaran yang umum digunakan di kelas yaitu model konvensional. Berdasarkan skor pretest, diketahui bahwa skor skor rata-rata kelas kontrol sebesar 45,82. Setelah dilakukan proses pembelajaran menggunakan model pembelajaran konvensional diperoleh skor rata-rata pretest sebesar 46,70 . Hal ini disebabkan karena pada kelas kontrol tidak dilakukan perlakuan seperti pada kelas eksperimen, dimana pada kelas kontrol menggunakan model yang umum digunakan di kelas yaitu model konvensional dengan metode ceramah. Siswa menjadi pasif karena hanya mendengarkan ceramah guru sehingga keterampilan berpikir kreatif mereka kurang terpupuk. Pada model pembelajaran ini guru lebih banyak melakukan kegiatan belajar mengajar dalam bentuk ceramah. Model ini berarti memberikan informasi satu arah sehingga yang ada hanyalah transfer pengetahuan dari guru kepada peserta didik tanpa adanya transfer keterampilan berpikir kreatif. Sedangkan skor rata-rata hasil pretest kelas eksperimen sebesar 49,76. Setelah dilakukan proses pembelajaran dengan menggunakan model PjBL, terdapat peningkatan. Skor rata-rata hasil postest kelas eksperimen menjadi sebesar 58,24. Hasil ini masih tergolong dalam kategori cukup. Hal ini diduga disebabkan beberapa faktor yaitu peserta didik belum terbiasa menggunakan model PjBL dan beberapa peserta didik belum berani mengemukakan pendapat maupun menjawab pertanyaan pada saat proses pembelajaran.

Tingginya rata-rata keterampilan berpikir kreatif pada kelas eksperimen dengan menggunakan model project based learning (PjBL) dibandingkan dengan model konvensional diduga terjadi karena model pembelajaran ini dapat memberikan kesempatan kepada guru untuk mengelola pembelajaran di kelas dengan melibatkan peserta didik dalam situasi dunia nyata, peserta didik secara berkelompok mengerjakan tugas proyek tentang daur ulang limbah organik berupa pembuatan pupuk kompos untuk mengurangi pencemaran lingkungan. Dengan demikian secara tidak langsung dapat melatih keterampilan berpikir kreatif peserta didik.

Model project-based learning (PjBL) memberi pengalaman belajar yang menarik dan bermakna bagi peserta didik. Hal ini sesuai dengan pendapat Made Wina dalam Al-Tabany (2017) yang mendefinisikan project-based learning/pembelajaran berbasis proyek sebagai model pembelajaran yang memberikan kesempatan kepada guru untuk mengelola pembelajaran di kelas dengan melibatkan kerja proyek. Kerja proyek adalah suatu bentuk kerja yang memuat tugas-tugas yang kompleks berdasarkan kepada pertanyaan dan permasalahan (problem) yang sangat menantang, menuntut peserta didik untuk merancang, memecahkan masalah, membuat keputusan, melakukan kegiatan investigasi, serta memberikan kesempatan kepada peserta didik untuk bekerja secara mandiri.

Model pembelajaran berbasis proyek sangat mendukung terwujudnya kompenen IPA yang meliputi proses dan produk karena dalam proses pembelajarannya guru memberikan 
Keterampilan Berpikir Kreatif Peserta Didik yang Diajar Melalui Model

Pembelajaran Pjbl dan Model Konvensional Materi Pencemaran

Lingkungan

p-ISSN 2621-5527

(hlm. 52-59)

proyek kepada peserta didik dan memberikan kesempatan kepada peserta didik mulai dari merencanakan, melaksanakan, mempresentasikan hasil karya mulai dari alat dan bahan yang digunakan, cara membuat, kegunaan, dengan demikian dapat membentuk berpikir kreatif pada diri peserta didik.

\section{Kesimpulan}

Berdasarkan hasil analisis data dan pembahasan dapat disimpulkan bahwa (1) keterampilan berpikir kreatif peserta didik yang diajar melalui model pembelajaran PjBL materi pencemaran lingkungan berada pada kategori cukup dengan nilai rata-rata sebesar 58,23, (2) keterampilan berpikir kreatif peserta didik yang diajar melalui model pembelajaran konvensional materi pencemaran lingkungan berada pada kategori kurang dengan nilai ratarata sebesar 46,70, (3) ada perbedaan keterampilan berpikir kreatif peserta didik yang diajar melalui model pembelajaran PjBL materi pencemaran lingkungan di SMP Negeri 1 Malili dimana peserta didik yang diajar melalui model pembelajaran PjBL memiliki keterampilan berpikir kreatif lebih tinggi dibanding yang diajar melalui model pembelajaran konvensional.

Melalui penelitian ini diharapkan kepada guru agar menjadikan model pembelajaran PjBL sebagai alternatif model pembelajaran biologi materi pencemaran lingkungan dalam meningkatkan keterampilan berpikir kreatif peserta didik. Penerapan model PjBL efektif membutuhkan banyak waktu sehingga lebih efektif dalam mengembangkan keterampilan berpikir kreatif peserta didik.

\section{Referensi}

Akbar, F., \& Arsad, B. (2017). Potensi Model PjBL (Project-Based Learning) dalam Meningkatkan Motivasi Belajar Peserta Didik dengan Gaya Belajar Berbeda. Jurnal Sainsmat. 6 (1).

Al-Tabany, T. I. B. (2017). Mendesain Model Pembelajaran Inovatif, Progresif, dan Kontekstual: Konsep, Landasan, dan Implementasinya pada Kurikulum 2013 (Kurikulum Tematik Integratif/KTI). Jakarta. PT Kharisma Putra Utama.

Luthfi, R. R. M., Ismail., \& Muhammad, W. (2018) Memberdayakan Keterampilan Berpikir Kreatif dan Self-Regulated Learning Peserta Didik Melalui Model Project Based Learning. Prosiding Seminar Nasional Biologi dan Pembelajarannya. Makassar. UNM.

Meika, I., \& Asep, S. (2017). Kemampuan Berpikir Kreatif Dan Pemecahan Masalah Matematis Siswa Sma. JPPM. 10(2).

Suriyani., Hasratuddin., \& Asmin. (2015). Peningkatan Kemampuan Berpikir Kreatif dan Kemandirian Belajar Siswa Mts Negeri 2 Medan melalui Pembelajaran Matematika dengan Pendekatan Open-Ended. Jurnal Tabularasa Pps Unimed. 12 (3).

Syamsu, S. A., Yunus, M., \& Masri, M. (2016). Penerapan Model Creative Problem Solving (CPS) untuk Meningkatkan Kemampuan Berpikir Kreatif Peserta Didik Kelas XI MIA 1 SMA Negeri 1 Bulukumba (Studi pada Materi Pokok Laju Reaksi). Jurnal Chemica. 17 (2). 
p-ISSN 2621-5527

e-ISSN 2621-5535
Keterampilan Berpikir Kreatif Peserta Didik yang Diajar Melalui Model

Pembelajaran Pjbl dan Model Konvensional Materi Pencemaran

Lingkungan

(hlm. 52-59)

\begin{tabular}{|l|l|}
\hline Sitti Ashriah & $\begin{array}{l}\text { S.Pd. Jurusan Biologi, Fakultas Matematika dan Ilmu Pengetahuan Alam, } \\
\text { Universitas Negeri Makassar } \\
\text { Email: sashriah@yahoo.com }\end{array}$ \\
\hline Abd. Muis & $\begin{array}{l}\text { M.Si, Dr. Dosen Jurusan Biologi, Fakultas Matematika dan Ilmu Pengetahuan } \\
\text { Alam, Universitas Negeri Makassar } \\
\text { Email: abdmuismuhsen2@gmail.com }\end{array}$ \\
\hline A. Faridah Arsal & $\begin{array}{l}\text { S.Si, M.Si, Dr. Dosen Jurusan Biologi, Fakultas Matematika dan Ilmu } \\
\text { Pengetahuan Alam, Universitas Negeri Makassar } \\
\text { Email: a.faridaharsal@gmail.com }\end{array}$ \\
\hline
\end{tabular}

